\title{
The Validity of Construct Analysis on Assessment Instrument of Basketball Skill for Senior High School in Yogyakarta City
}

\author{
Budi Aryanto $^{1, *}$, Pamuji Sukoco², Ria Lumintuarso ${ }^{3}$ \\ ${ }^{1}$ Doctoral Program of Educational Research and Evaluation Department, Yogyakarta State University, Indonesia \\ ${ }^{2}$ Study Program of Physical Education, Sanity, and Recreation, Faculty of Sport Science, State University of Yogyakarta, Indonesia \\ ${ }^{3}$ Study Program of Sport Coaching, Faculty of Sport Science, State University of Yogyakarta, Indonesia
}

Received July 26, 2020; Revised August 27, 2020; Accepted September 29, 2020

\begin{abstract}
Cite This Paper in the following Citation Styles
(a): [1] Budi Aryanto, Pamuji Sukoco, Ria Lumintuarso, "The Validity of Construct Analysis on Assessment Instrument of Basketball Skill for Senior High School in Yogyakarta City," International Journal of Human Movement and Sports Sciences, Vol. 8, No. 5, pp. 193 - 198, 2020. DOI: 10.13189/saj.2020.080506.
\end{abstract}

(b): Budi Aryanto, Pamuji Sukoco, Ria Lumintuarso (2020). The Validity of Construct Analysis on Assessment Instrument of Basketball Skill for Senior High School in Yogyakarta City. International Journal of Human Movement and Sports Sciences, 8(5), 193 - 198. DOI: 10.13189/saj.2020.080506.

Copyright $\bigcirc 2020$ by authors, all rights reserved. Authors agree that this article remains permanently open access under the terms of the Creative Commons Attribution License 4.0 International License

\begin{abstract}
This research is quantitative research which aims to know the quality of instrument proved by the validity of construct. The empirical validity of research instrument is tested to senior high school students both public and private school in Special Region of Yogyakarta which hold the basketball competition among senior high school. The result of tested then is analyzed by using exploratory factor analysis (EFA) and confirmatory factor analysis (CFA). The EFA analysis uses software support of SPSS 23.0 and CFA analysis uses software LISREL 8.8. The result of analysis by EFA shows that the grouping data into two big groups such as skill execution and decision making. The result analysis of EFA also shows that the value of KMO is about $0.747>0.50$. The value of Bartlett's test and Chi-square is about 318.020 and the significance is on 0.000 , therefore the analysis tested factor can be continued. The result of assessment calculation of basketball skill by using first order CFA shows that the value of $p$-value $=0.16220(>0.05)$, RMSEA $=0.042(>0.08)$ and chi-square $=11.76>0.05$ which means that the model is appropriate with the data, the analysis of model structural equation, and decision making effect the ability of playing basketball. The amount of contribution of decision making toward the ability of playing basketball is about 26 percent, while the contribution is about 74 percent influenced by another variable.
\end{abstract}

Keywords Exploratory Factor Analysis, Confirmatory Factor Analysis, Assessment, Basketball

\section{Background of Study}

According to FIBA in Official Basketball Rules 2012 basketball game defined as follow, basketball game is played by two teams which is each team consists of five players. The aim of this game is by putting the ball into the rival team's basket and trying to prevent the rival team to put the ball into the basket. The game is controlled by referee, desk clerk, and match overseer. The basket attacked is called rival's basket and the basket guarded is called team's basket. The team obtained bigger score is the team winning the game. Basketball game is included in invasion game such as football, handball, and hockey which cooperates among the players in one team to reach the goal of getting the score and preventing the rival team getting the score [1].

The basic skill of basketball player according to Morrow et. al [2] consists of shooting, dribble, passing the ball and jumping. The next progress, proposed by Memmert and Harvey [3], it depends on the game and the category, teachers, coaches or researcher can choose one of or 
several components of Game Performance Assessment Instrument (GPAI) to evaluate the someone's performance in playing basketball. Two advantages are by using Game Performance Assessment Instrument (GPAI) to evaluate someone's ability in sport, such as (a) Game Performance Assessment Instrument (GPAI) is easily adapted for various kind of sport, physical activity, and (b) GPAI has the ability to measure the skill in processing the ball, but also the skill without mastering the ball (measuring the offensive or defense) [1]. For example, in invasion (including playing basketball), a teacher, coach, or researcher only chooses assessing the component in attacking, skill execution and decision making, or assessing the component in defending, guard or support.

In this research GPAI developed for assessing the ability of the player in playing basketball after doing practice of basketball. More specific for coaching in basketball sport. Game Performance Assessment Instrument (GPAI) is also developed but only taking the component of skill execution and decision making.

Skill execution is player's ability to show the performance which efficient from one skill chosen. In basketball game, there are only three basic skills in playing, such as shooting, passing and dribbling. Appropriate with the definition above, skill execution for on-the-ball in playing basketball is an efficient performance in doing the skill in shooting, passing and dribbling. According to Gutierrez et. al [4] and Memmert and Harvey [3], skill execution got value 1 if it is successful or effective and value 0 if it isn't successful or ineffective.

Decision making is player's ability in making choice of the right skill appropriate with the situation when the player mastering the ball. Assessing the decision making is also done by two ways: decision making which is appropriate or right getting value 1 and decision making which is not appropriate or incorrect getting value 0 .

On the principle of assessing by using GPAI is an assessment which is called authentic assessment. Authentic assessment is defined as the assessment of performance based [5]. Authentic assessment has the equivalent of other names such as alternative assessment, performance assessment and direct assessment.

Authentic assessment is direct assessment and using direct size, when doing this assessment, there are many activities which are clearer if they are assessed directly. In this research, the activity of playing basketball needs direct assessment to be able to assess the skill of playing basketball. Authentic assessment is an assessment which asked students to perform the task in real situation by demonstrating the skill applying and meaningful knowledge. The performance needed to be present effectively and creatively. Authentic assessment usually involves a task to be performed and the criteria of assessment or rubric which will be used to assess the performance.

Measuring can be defined as a process collecting information by the rule of giving number or value on the object or certain event by systematic ways. The process of measurement including two things such as determining what will be measured and choosing the instrument to measure what will be measured. The common instrument used by teacher of sport education is various kinds of sport skill test and the test of physical freshness. There are three important elements related with the measuring such as object measured, instrument, unit of measure used by the object which will be measured usually related to the physical condition or someone's phycologist. The instrument used is categorized into two categories such as standard and not standard instrument. Unit of measure of each object is different one to another, though there is a possibility that object measured is the same object, but using different instrument. To measure physical object, the unit of measuring used like the lengthy stated by meter units. For non-physical object such as attitude, perception, motivation and etc., needs the unit of measure made by the researcher that can state quantitative measurement.

In order to make measurement done optimally, it should use the unit of measure which can be able to obtain the accurate information, properly, and relevant. Therefor the instrument used should fulfill the standard instrument required. Related to the statement of Ngatman [6], that the process evaluation in physical education can run well, all the instruments used should have good characteristics. Miller [7] states that a sport skill should fulfill some requirements such as it should be valid, reliable, objective, economist, interesting and proven can be implemented.

Mardapi [8] defines the validity as the size of how careful a test does its measuring function. American Educational Research Association (AERA), American Psychological Association (APA), National Council on Measurement in Education (NCME) define a validity as, how far the prove and the theory supported the specific interpretation from test required by the using proposed. The test validity refers to the level of truth in score test interpretation. This interpretation based on the aims of test using [9]. The validity is how far the accumulation of certain interpretation proof and supported theory from score test by the use and validity refers to the level of truth of score test interpretation on its use.

Saifuddin [10] divides the type of validity from the way of estimation adjusted with the character and function every test to be three categories such as content validity, construct validity, criterion related validity.

Construct validity is a type of validity which shows how far the test revealed a trait or theoretic construct which is measured [11]. According to Mardapi [12] the validity of content is observed from the grid of test such as matrix showing the material test as well the level of thinking involved in doing the test. This validity is analyzed before the test used. Construct validity is obtained from the result of analyzing factor including the number of factors measured of a test. The proof of validity construct is 
obtained from the result of test using, such as empirical data. The opinion is confirmed by Saifuddin [10], the result of estimation construct is not stated in the form of validity coefficient. Examining the construct validity can also be a technique of statistics analyzing. In its analyzing done by examining the relationship between the items and the factors, so it is called factor analysis. Instrument can be valid if the items are really revealed and applicable as the factor of indicator which can be measured. By contract validity, the researcher sets the construct or concept which will be measured then set the indicators which will be developed next to be items of questions.

Some of studies about the skill in psychomotor assess the technique of playing basketball have been done [13]. Most of them develop the test skill in sport skill test. There is no research yet about skill in playing basketball which assesses about psychomotor skill, affective and cognitive at ones. The test the ability of playing basketball developed in abroad is the test of basketball created by Hopkins, Shicks, $\&$ Plack [14]. In Indonesia, there are some studies related to the developing the test of playing basketball skill. The study from Budi Aryanto adaption of skill test of AAHPERD 1984 (1996).

Though there have been studies about skill test of playing basketball for elementary, junior and high school level, but until now days, the data of skill level of playing basketball from each level of school have never been published. Until now, there have been not data of how far the skill level of playing basketball of senior high school students in Indonesia. If there is a study revealed about the skill level, the data taken in this research have purposive character and cannot be generalized. The main key of prestige improvement in the context of basketball coaching is observation of player's skill, and it can be done by doing the match analysis and testing skill. Based on the description delivered, this research focused on the construct validity of assessment instrument of basketball skill. Construct validity is expected to be able to prove the result of measuring obtained through items of test is high correlation with theoretical construct which underlies instrument drafting.

\section{Methodology}

This research is basically quantitative research which aims to know the quality of instrument proven through the construct validity. Empirical validity of research instrument planned tested to the senior high school students both public and private school in Special Region of Yogyakarta which hold basketball competition among senior high school. The result of tested then is analyzed by using exploratory factor analysis and confirmatory factor analysis. The analysis of EFA uses software supported of SPSS 23.0 and CFA uses software LISREL 8.8.

This tested is done by assessing the ability of the player when they are playing basketball in the competition of DBL 2019 region, Special Region of Yogyakarta. The assessment includes skill execution and decision making. The number of respondents is 250 players. The players playing in personal identity data then during playing they are assessed with two instruments above.

Construct validity gives the proof that the result of measurement is really can be interpreted related to the definition, or the instrument really reveals the skill measured. Instrument validity is based on the empirical data analyzed using confirmatory factor analysis [15]. Construct validity is proven by using loading factor data obtained from CTA. An observation variable is stated to be valid if measuring the variable is latent if the number of factor load is bigger than 0.3 . In this research the construct validity is tested by using first order of CFA with software LISREL 8.8 supported.

First order CFA equation can be formed:

$$
\chi \mathrm{p}=\lambda \mathrm{p} \xi+\delta \mathrm{p}
$$

Where $\chi 1, \chi 2, \ldots \chi p$ is the indicator from common factor. $\lambda 1, \lambda 2 \ldots \lambda \mathrm{p}$ is loading factor, $\delta 1, \delta 2, \ldots \delta \mathrm{p}$ is unique factor for each error equation. The relation between first order CFA and second order CFA, is formed as equation below:

$$
\begin{gathered}
\eta=\mathbf{B} \eta+\Gamma \xi+\zeta \\
\mathbf{X}=\boldsymbol{\Lambda} \mathbf{x} \eta+\varepsilon
\end{gathered}
$$

Where $\mathbf{B}$ is coefficient loading, $\Gamma$ and $\Lambda$ are loading factors first order and second order, $\xi$ random vector of latent variable, $\varepsilon$ is residual (Brown, 2006: 321).

\section{Result and Discussion}

\subsection{Exploratory Factor Analysis (EFA)}

Factor analysis is used in this tested of this small-scale use exploratory factor analysis. The principle of exploratory factor analysis is grouping the data based on the intercorrelation among the items. The result obtained from the analysis is statistical analysis which is rotated component matrix. Extraction analysis to explore the number of dimensions is wanted by instrument developed. The table on the rotated component matrix shows that the distribution of the test is on the variable on the number of factors existed. While, the number found in the table is factor loading or the number of intercorrelation among the variable of test with the factor existing.

Based on the result from exploratory factor analysis, it is then interpreted to set whether an item is abort or not. The criteria used are based on the opinion expressed by Safrit and Wood [16], if an item has factor loading under 0.30, so the item is abord. Factor analysis in this research is done by using computer program supporting SPSS 23.0 version.

Assumption underlying whether factor analysis can be used or not is matrix data should have sufficient correlation. 
The test of Bartlett of Sphericity is statistical tested to determine the number of correlations among variable which can be tested. Another test instrument used to measure the level of intercorrelation among variable and whether analysis factor can be done or not is Kaiser-Meyer-Olkin Measure of Sampling Adequacy (KMO MSA).

Table 1. KMO test \& Bartlet

\begin{tabular}{lcc}
\hline \multicolumn{3}{c}{ KMO and Bartlett's Test } \\
\hline Kaiser-Meyer-Olkin Measure of Sampling Adequacy. & .713 \\
& Approx. Chi-Square & 185.677 \\
Bartlett's Test of Sphericity & Df & 15 \\
& Sig. & .000 \\
\hline
\end{tabular}

The value of KMO MSA should be bigger than 0.50 to be able to do factor analysis. The result display of output SPSS shows the value of KMO is about 0.713 , therefore it can be done factor analysis. The value of Bartlett test with Chi-square is about 185.677 and the significance is 0.000 , so it can be concluded that the test of factor analysis can be continued.

Based on the data analyzing done with computer supported from sixth variables analyzed found that the result of computer extraction is divided into two factors based on the value of eigen value $>1$, factor 1 with the eigen value 3.321 , factor 2 with eigen value 1.584 . factor 1 is able to explain the variation which is about 55,356 percent. Factor 2 is able to explain the variation which is about 26.393 percent, both of factors are able to explain the variation which about 81.749 percent.

By looking at the component matrix and varimax rotated component matrix, it is clear that grouping in the factor 1 is shooting skill execution, passing skill execution, and dribble skill execution which all the loading factor is about 0.866. while grouping in the factor 2 is shooting decision making, passing decision making and dribble decision making which each loading factor is about 0.831 .

Tabel 3. Component Matrix and Rotated Component Matrix EFA
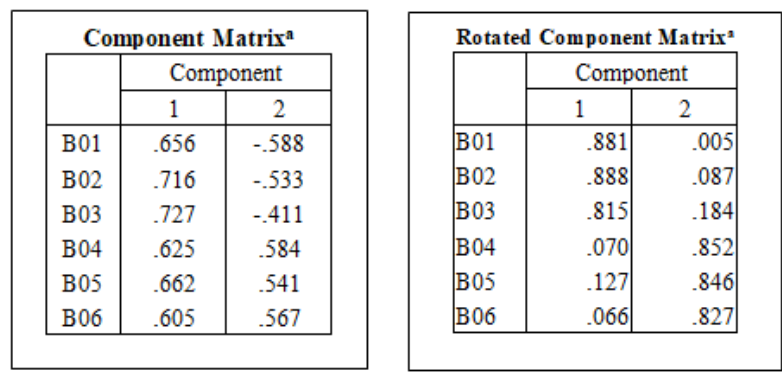

The tested with big scale skill assessment of playing basketball is done toward the basketball male player of senior high school in Special Region of Yogyakarta. This tested done by assessing the player's skill when they are playing basketball in the competition of DBL 2019 region, Special Region of Yogyakarta. The assessment includes skill execution and decision making. The number of respondents is 250 players. The player playing in personal identity data then during playing, they are assessed with two instruments above.

Analysis in developing the instrument aims to know the validity and reliability of instrument. Data analyzing is to know the construct validity instrument is done by confirmatory factor analysis (CFA) using LISREL 8.8 supported.

Criteria used to set the validity of instrument for CFA tested are by looking at the number of loading factor has by each item of instrument. The number of loading factor can be known when doing CFA. The provision used for validity boundary is 0.3 . to know the reliability of instrument, criteria used to set the reliability of instrument is by looking at the number of construct reliability $(\mathrm{CR}) \geq$ 0.7 .

Table 2. Eigen Value of EFA

Total Variance Explained

\begin{tabular}{cccccccccc}
\hline & Total & \% of Variance & Cumulative $\%$ & Total & \% of Variance & Cumulative \% & Total & \% of Variance & Cumulative \% \\
\hline 1 & 3,321 & 55,356 & 55,356 & 3,321 & 55,356 & 55,356 & 2,501 & 41,685 & 41,685 \\
2 & 1,584 & 26,393 & 81,749 & 1,584 & 26,393 & 81,749 & 2,404 & 40,064 & 81,749 \\
3 &, 418 & 6,971 & 88,720 & & & & & & \\
4 &, 266 & 4,431 & 93,151 & & & & & & \\
5 &, 242 & 4,040 & 97,191 & & & & & & \\
6 &, 169 & 2,809 & 100,000 & & & & & & \\
\hline
\end{tabular}




\subsection{Confirmatory Factor Analysis (CFA)}

Big scale assessment tested of playing basketball skill is done toward the male player of basketball of senior high school in Special Region of Yogyakarta. This tested done by assessing the ability of the player when they are playing basketball in the competition of DBL 2019 region, Special Region of Yogyakarta. The assessment including skill execution and decision making. The number of respondents is 250 players. The player playing in personal identity data then during playing they are assessed with two instruments above.

Analysis in developing the instrument aims to know the validity and reliability of instrument. Data analyzing is to know the construct validity instrument done by confirmatory factor analysis (CFA) using LISREL 8.8 supported.

Criteria used to set the validity of instrument for CFA tested are by looking at the number of loading factor has by each item of instrument. The number of loading factor can be known when doing CFA. The provision used for validity boundary is 0.3 . to know the reliability of instrument, criteria used to set the reliability of instrument are by looking at the number of construct reliability $(\mathrm{CR}) \geq$ 0.7 .

Table 4. Tested Result of Confirmatory Factor Analysis

\begin{tabular}{ccccc}
\hline \multirow{2}{*}{ Factor } & \multirow{2}{*}{ Item } & \multicolumn{3}{c}{ Confirmatory Factor Analysis } \\
\cline { 3 - 5 } & & $\mathrm{LF}$ & $\mathrm{t}$-Val & $\mathrm{CR}$ \\
\hline \multirow{2}{*}{ Skill } & SE Shooting & 0.87 & 16,29 & \\
Execution & SE Passing & 0.90 & 17,22 & 0,877 \\
& SE Dribbling & 0.74 & 12,99 & \\
Decision & DM Shooting & 0.78 & 12,90 & \\
Making & DM Passing & 0.81 & 13.31 & 0,804 \\
& DM Dribbling & 0.69 & 10,88 & \\
\hline
\end{tabular}

Analysis result of first order CFA on the table 4 above shoe that all of items instrument on the factor of skill execution and decision making have loading factor bigger than 0.30 , therefore all of the instrument items are valid. Besides, skill execution and decision-making construct reliability $\geq 0.7$, therefore it can be stated that the instrument is reliable.

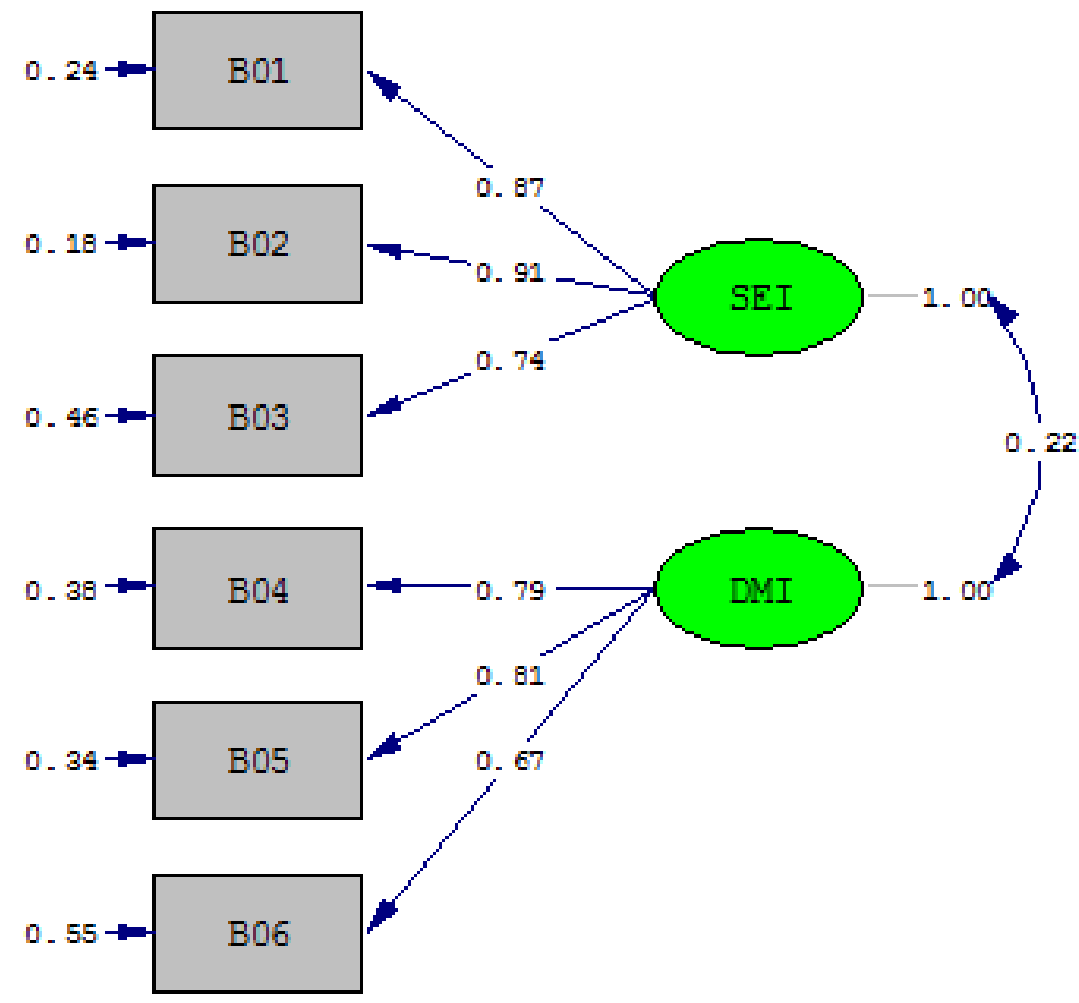

Chi-Square=11.76, df=8, P-value=0.16230, RMSEA=0.043

Picture 1. Path Diagram Standard Solution First Order CFA Skill Execution and Decision-Making big scale tested 


\section{Conclusions}

Construct assessment of playing basketball skill consists of assessment toward skill execution and decision making. In skill execution and decision making, there are three basic components of playing basketball assessed such as shooting, passing and dribbling. This case proven by EFA and CFA first order tested. The analysis result with EFA shows that grouping the data into two big groups such as skill execution and decision making. The analysis result with EFA also shows that the value of KMO about 0.747 is bigger than 0.50. the Bartlett's test with Chi-square is about 318.020 and the significance in 0.000 . therefore, the test of factor analysis can be continued. The calculation result assessment of the skill playing basketball by using first order CFA shows that the value of $p$-value $=0.16220$ (bigger than 0.05), RMSEA $=0.042$ (smaller than 0.08) and Chi-square $=11.76$ is bigger than 0.05 which means that the model is convenient with the data. The component giving the biggest contribution toward skill execution variable is passing component which is about 91 percent while the component giving the smallest contribution is dribbling component which is about 74 percent. The component giving the biggest contribution to the variable of decision making is passing component which is about 81 percent while the component giving the smallest contribution is dribbling component which is about 67 percent. Based on analysis of structural equation model, skill execution effects the skill of playing basketball. The number contribution of skill execution toward the skill of playing basketball is about 21 percent. While the contribution which is about 79 percent is influenced by another variable.

Based on the analysis of structural equation model, decision making influence the skill of playing basketball. The number of contributions of decision making toward the skill of playing basketball is about 26 percent, while the contribution which is about 74 percent is influenced by another variable.

\section{REFERENCES}

[1] Mitchell, S.A., Oslin, J.L., \& Griffin, L.L. (2006). Teaching Sport Concept and Skills A Tactical Games Approach $2^{\text {nd }}$ edition. USA: Human Kinetics.
[2] Morrow, J.R. Jr; Jackson, A.W; Disch, J.G; \& Mood, D.P. (2005). Measurement and evaluation in human performance $3^{\text {rd }}$ edition. USA: Human Kinetics.

[3] Memmert, Daniel \& Harvey, Steve (2008) The Game Performance Assessment Instrument (GPAI): Some Concerns and Solutions for Further Development, Journal of Teaching in Physical Education Volume 27 p 220-240.

[4] Gutierrez, D., Fisette, J., Garcia-Lopez, LM., \& Contreras, O. (2014). Assessment of Secondary School Students Game Performance Related to Tactical Context, Journal of Human Kinetics, Volume 42 p 223-234.

[5] Rustaman, N.Y. (2010). Penilaian Otentik (Authentic Assessment) dan Penerapannya dalam Pendidikan Sains. Bandung: UPI.

[6] Ngatman (2003). Tes dan pengukuran dalam pendidikan jasmani, Olahraga Majalah Ilmiah, Volume 9 Agustus 2003, 46-63.

[7] Miller, D.K (2002) Measurement by the physical educator $4^{\text {th }}$ edition. San Fransisco: McGraww Hill.

[8] Mardapi, Djemari. (2004). Pengembangan sistem penilaian berbasis kompetensi. Disampaikan pada Seminar HEPI "Rekayasa Sistem Penilaian untuk Meningkatkan Kualitas Pendidikan" Yogyakarta 26-27 Maret 2004.

[9] Mardapi, Djemari. (2008). Teknik penyusunan tes \& non tes. Yogyakarta: Mitra Cendikia Press.

[10] Azwar, Saifuddin. (2007). Dasar-dasar psikometri. Ed. II. Yogyakarta: Pustaka Pelajar.

[11] Allen, M.J. \& Yen, W.M. (1979). Introduction to measurement theory. California: Brooks/Cole Publishing Company.

[12] Mardapi, Djemari. (2012). Pengukuran, Penilaian dan Evaluasi Pendidikan. Yogyakarta: Nuha Medika.

[13] Seyfi Savaş, Mehmet Fatih Yüksel, Ahmet Uzun, (2018). The Effects of Rapid Strength and Shooting Training Applied to Professional Basketball Players on the Shot Percentage Level. Universal Journal of Educational Research, 6(7), 1569 - 1574. DOI: 10.13189/ujer.2018.0607 17.

[14] FIBA (2012). Official basketball rules 2006. Hong Kong: FIBA.

[15] Mueller, J. (2013). Authentic Assessment. North Central College. Tersedia: http://jfmueller.faculty.noctrl.edu/toolbo $\mathrm{x} /$ whatisist.htm

[16] Safrit, M.J \& Wood, T.M (1989). Measurement concept in physical education and exercise science. Illionois: Human Kinetics Books. 